the appropriate infinite series. His approach is both rigorous and practical; that of Maak, while attractive, is so polished and lengthy that none but the chosen few in the mathematical class can take it. In trying to reconcile these two books, perhaps the proper view is to regard Rankin's book as a prior text, and a very good text-book it is, and Maak's book as one of reference by those who already know the subject.

One half of Prof. R. A. Rankin's book is given to integration and to convergence and uniformity. A few words about the former may not be out of place. Two points of view are adopted. In the first, integration is defined as the reverse process to differentiation, and this approach leads to the standard results of the theory quite quickly. In the second the Riemann-Stieltjes integral and the Riemann integral are introduced, the theory being based largely on the properties of interval functions and dissections that are studied previously. Once again the sound practical approach to the subject is evident.

Prof. Rankin's book is a first-class text for undergraduate classes. Not only are numerous exercises provided but also hints for the solutions of many of these are given. It is a gentle text and will form a most valuable adjunct to a course of lectures on the subject.

L. S. GODDARD

\section{STRUCTURE AND MEANING}

\section{Structural Anthropology}

By Dr. Claude Lévi-Strauss. Translated from the French by Claire Jacobson and B. G. Schoopf. Pp. xvi+4l0. (New York and London: Basic Books, Inc., 1963.) 52s. $6 d$.

$A^{N Y}$ professional teacher of social anthropology (say, $A$ any one of the 200 or so members of the Association of Social Anthropologists) must be competent to write a conventional introduction to the subject, that is, to the work of other people, for if he could not so order the elementary instruction which he provides he should not occupy a university position. To receive Structural Anthropology, therefore, as yet one more text-book would to be encourage no special expectation. Prof. LéviStrauss, by contrast, is not only one of the extremely few scholars of sufficient distinction to be able to say, without presumption, what social anthropology is about; but he has also actually demonstrated, by numerous analytical articles and monographs, that he is pre-eminently worth listening to. $\mathrm{He}$ does not just talk about the subject, he works; he does not simply practise social anthropology, he makes exciting and original contributions to it.

Yet this collection of some of his papers, although the nearest thing so far published to a representative introduction to social anthropology, novertheless shows that a text-book of the subject is not possible. It has, to begin with, no distinctive subject-matter, and it possesses no singular method of analysis. Lévi-Strauss demonstrates the former point by writing about a wide range of disparate topics such as sentiments, dual organization, sorcery, myth, symbolism, dialectics, and split representation, taken from a variety of both great and minor civilizations; and he makes the second by constant references to history, linguistics, communications theory, and physies. What is it, then, that he and the discipline of which he is the foremost theoretical proponent have to offer to human understanding?

The most concise response is that social anthropology is the structural analysis of meaning. Its focal concerns are social categories, relations, and values; its characteristic objects of examination are symbols. The source of the special authority of the social anthropologist in this extensive and general field of investigation is the universal scale against which he pursues his enquiries, so that when he tries to construct general propositions (as, of course, do historians or economists) he alone may properly aim at complete generality within the territorial and temporal limits of mankind. Thus Lévi-Strauss deals, in one essay, with material and with periods as greatly dispersed as China in the first to second millennia B.C., the Amur region in the prehistoric era, Brazil in the twentieth century, and New Zealand in the fourteenth to eighteenth centuries. The social anthropologist cannot be a polymath to the extent of possessing a scholarly command of all that is known about every area and period, but the breadth of his comparisons and the abstract nature of his discipline as a general theory of relations permit him, nevertheless, to advance novel and empirical considerations.

$A$ priori, it would seem unlikely that this result might be possible, but Prof. Lévi-Strauss is superbly capable of demonstrating that it is. He does so in the main not by concentration on substantive cultural particulars but by analysis in such relational terms as opposition, reciprocity, and homology, and it is through the structural models thus constructed that he is able to encompass such a mass of apparently incomparable evidence. How he does so is not a matter for report but for examination, and anybody who thinks such an enterprise worthy of attention should learn much from reading this volume. But even LéviStrauss cannot be taken as an exact exemplar in all respects, and the most prominent ground for demur concerns the relationship of his own work to linguistics, the subject to which he so frequently has recourse in his methodological observations. He makes many professions of illumination yielded by linguistics, and generously concedes priority to it as a field of more advanced structural analysis; but it is a question whether social anthropology has ever profited in one clear respect from the example of that admirable discipline. The parallels of concept and method to which Lévi-Strauss alludes are indeed noteworthy, but it is arguable that they are no more than parallels, for the principles implicit in his work are readily discernible in Dumézil also, in Hocart and in Rivers, and of course in Mauss and Hertz and Durkheim. The structuralist approach which these scholars have used, in a long and continuing tradition of ideas, owes nothing historically and particularly to linguistics; nor is there to be found in linguistics to-day, for example in the algebraic tautologies of the so-called "componential analysis of kinship", any more immediate or useful effect. We should instead take it, therefore, that Lévi-Strauss has merely found in the terminology of linguistics a technical idiom which appeals to him, rather as Dr. E. R. Leach (Lévi-Strauss's counterpart in Britain) has found it convenient to make a similar comparison with topology. This view is not merely a suggested qualification to be kept in mind when reading Lévi-Strauss's papers, but, if accepted, it has the result of at once making his thought more directly accessible to understanding, and placing him in a recognized tradition proper to his discipline.

What this diseipline is, to return, may be illustratednot catalogued-by the papers in Structural Anthropology. They are divided into five sections: language and kinship; social organization; myth and religion; art; and problems of method and teaching. The seventeen articles were originally published, all but four in French, between the years 1945-56 (the collection could be marvellously amplified with other papers published since), and have beon translated into an exact and fluent English by Claire Jacobson, with the collaboration of Brooke Grundfest Schoepf. A random check reveals small uncertainties, or even a misrendoring such as "generalized reciprocity" for the key term "échange géneralise", but in general the translation is excellently worthy of the author. There is a full bibliography and a good index. The volume is most handsomely produced, and it is only to be regretted that the American publishers (unlike the original French) should have found it expedient to put the footnotes exasperatingly at the end of each article instead of where they belong.
R. NEEDHAM 